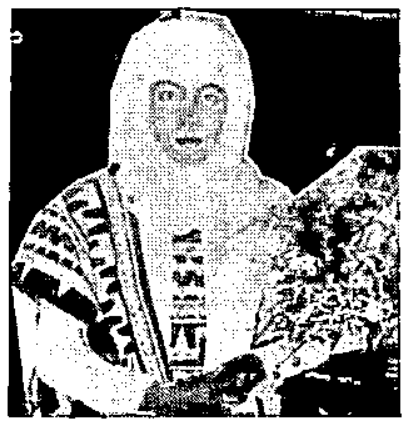

\title{
BENANG MERAH ANTARA \\ GSP, KONDISI \\ PERBURUHAN, DAN \\ POLITIK LUAR NEGERI \\ INDONESIA.
}

O1:en Setrinit

Sebagai akibat perkembangan globalisasi. saat ini salah satunya yaitu terjadinya ketimpangan politis dalam pembagian distribudi ekonomi. Hal ini terlihat jelas ketika AS selaku negara adikuasa mengaitkan berbagai aktivitas bisnisnya termasuk GSP dengan kondisi HAM di Indonesia. Namun, menurut Sefriani, hal ini ada hikmahnya bagi kita yaitu agar pemerintah kita semakin meningkatkan taraf hidup buruhnya sehingga tidak dimanfaatkan oleh negara lain untuk kepentingan-kepentingaanya.

\section{Pendahuluan}

Awal Pebruari yang lalu, hampir semua surat kabar baik lokal maupun nasional menjadi masalah GSP sebagai topik utama beritanya. Berbagai kalangan, mulai anggota DPR, mentri, Para Pakar dan pengamat juga para mahasiswa beradu argumentasi tentang adanya ancaman pencabutan fasilitas GSP (Generalized System of Preferences) oleh Amerika Serikat terhadap produk-produk ekspor dari Indonesia ke negara adikuasa itu. Jumlah ekspor Indonesia sendiri kurang Iebih 460 juta dolar Amerika Serikat.

Ancaman pencabutan fasilitas keringanan be masuk produk ekspor ke Amerika Serikat ini bermula dari petisi yang diajukan oleh Asia Watch (AW) dan International Labour
Rights Education. and Research Fund (ILRERF), dua LSM yang berkedudukan di Washington, kepada United States Trade Representative (USTR) untuk mencabut fasilitas GSP bagi Indonesia. ${ }^{1)}$

Secara spesifik. ada 4 hal pokok yangmenjadi landasan diajukannya petisi tersebut ${ }^{2)}$ : Yang pertama adalah tidak adanya jaminan pembentukan serikat buruh di Indonesia, Kemudian berikutnya berturut-turut adalah adanya campur tangan militer dalam konflik perburuhan, tidak adanya kemudahan dalam membuat perjanjian kerja kolektif, serta yang terakhir

1) Jawa Pos, 15 Pebruari 1994

2) Republika, 18 Pebruari 1994 
tidak adanya keterbukaan terhadap organisasi buruh asing di Indonesia.

Terahadap ancaman ini sebagian besar pihak hanya menilainya tak lebih dari sekedar gertak sambal semata. Pada dasamya ancaman serupa memang sudah bukan barang baru lagi. Hampir setiap tahun sejak tahun 1987, ancaman-ancaman serupa ini ada, tapi toh fasilitas GSP itu tetap diberikan samapi saat ini. Tambahan lagi sudah bukan merupakan rahasia lagi, hobby Amerika Serikat menggunakan penetrasi-penetrasi dengan mengatas namakan pelanggaraan hak asasi manusia terhadap negara-negara yang ingin mendapatkan fasilitas-fasilitas atau bantuan-bantuannya. Tidak hanya terhadap Indonesia, beberapa waktu yang lalu sempat memanas hubungan Amerika Serikat dengan Cina karena ancaman negeri Paman Sam ini mencabut status MFN (Most Favaored Nation) yang diberikan Amerikat Serikat pada Cina. Alasan yang dikemukakan Amerika Serikat adalah pelanggaran hak asasi manusia yang dilakukan Cina terhadap pemberontak Tian Meng. Cina berang karena menganggap Amerika Serikat terlalu mencampuri urusan dalam negerinya, dan tidak gentar terhadap ancaman Amerika itu. Kembali ke kasus ancaman pencabutan GSP bagi Indonesia, prediksi di atas terbukti benar adanya. Mesti sempat membuat sport jantung berbagai kalangan, khususnya para pengusaha, tanggal 15 Pebruari yang lalu pihak Amerika mengumumkan perpanjangan pemberian fasilitas GSP untuk enam bulan lagi.

Perpanjangan ini diberikan untuk memberi kesempatan bagi Pemerintah Indonesia untuk lebih memperbaiki kondisi perburuhannya. Pihak Amerika Serikat melihat, ada etikad baik dari Pemerintah Indonesia ke arah itu, yakni dengan telah di keluarkannya Surat keputusan menteri Tenaga Kerja Nomor Kep 461/Men/1993 yang menaikan ketentuan upah minimum regional (UMR) dari $R p$ 3.100,- menjadi $R p$ 3.800,- untuk kawasab Jabotabek dan empat kawasan di Jawa Barat. ${ }^{3}$ Juga diterbitkannya Surat Keputusan Nomor 15 A Tahun 1994 tentang petunjuk penyelesaian perselisihan hubungan industrial dan PHK di tingkat perusahaan pemerintah. Keputusan ini menggantikan Surat Keputusan Menteri Tenaga Kerja Nomor 342 Tahun 1986 yang selalu mendapat kecaman karena melegitimasi intervensi militer dalam konflik perburuhan, sehingga membuat Departemen Tenaga Kerja lebih memihak pada pengusaha. Disamping itu juga diterbitkan Peraturan Nomor 01 Tahun 1994 tentan Serikat Pekerja tingkat perusahaan. ${ }^{4}$

Masih tentang tanggapan atas adanya ancaman pencabutan GSP ini, banyak pihak termasuk Menteri Luar Negeri Ali Alatas berpendapat bahwa kita tak perlu takut terhadap ancaman itu. Pun seandainya benar-benar dilaksanakan oleh Amerika serikat dan bukan hanya sekedar gertak sambal. Sebagai negar merdeka, Indonesia harus bisa mandiri, tidak menggantungkan diri pada bantuan-bantuan dan fasilitas dari negara lain. Apalagi jika bantuan itu dikaitkan dengan urusan domestik Indonesia. Sampai tahunn 1992, menurut Direktur Jenderal Perdagangan Luar Negeri Departemen Perdagangan dalam salah satu dengar pendapat dengan komisi VII DPR-RI yang baru lalu, total ekspor Indonesia Ke Amerika Serikat yang berhak memperoleh GSP mencapai kurang lebih 1,151 milyar dolar Amerika Serikat. Dari nilai ini, sekitar 200 juta dolar sengaja tidak dimintakan fasilitas GSP lantaran prosedurnya dianggap terlalu rumit dan berbelit-belit, serta perbedaan bea masuk yang relatif terlalu kecil untuk dimintakan GSP. Selain daripada itu, sekitar 
300 juta dolar memang tidak di beri fasilitas GSP, karena dipandang tidak memenuhi persyaratan yang ditentukan. Dengan demikian. praktis produk ekspor Indonesia ke Amerika Serikat yang mendapat failitas GSP hanya sekita 640 juta dolar Amerika Serikat. ${ }^{5)}$ Oleh karena itu, menurut berbagai pihak tadi tidak sepandan dengan nilai tukar yang ditentukan oleh pihak Amerika.

Terlepas dari berbagai pendapat yang ada, tulisan berikut mencoba untuk mengupas tentang sejarah GSP, politik luar negeri RI, kondisi perburuan di Indonesia, serta yang terpenting adalah hikmah apakah yang dapat kita ambil dari kasus ini.

\section{GSP dan Sejarahnya}

Sistem Preferensi Umum (SPU) atau GSP adalah suatu sistem yang di kenal dalam dunia perdagangan internasional, yang berupa pemberian fasilitas penurunan ataupun penghapusan tarif masuk barang-barang produk impor yang berasal dari negara-negara berkembang, agar dapat bersaing efektif dengan produk-produk dari negara-negara maju. ${ }^{6}$ )

Pengakuan dan pemberian fasilitas GSP oleh negara-negara maju ini tak lepas dari perjuangan United Nations Conference on Trade and Development (UNCTAD) dan kelompok 77. Pada sidang UNCTAD yang pertama kali di Jenewa 1964, kelompok negara-negara berkembang yang tergabung dalam kelompok 77 mengemukakan ketidakpuasannya dengan sistem perdagangan internasional dan konvensi-konvensi yang berlaku saat ini.

- Pasal 1 ketentuan GATT (General Agreement of Tariffs and Trade) mengatur tentang MFN. Setiap negara dalam GATT membuka pasarnya secara adil untuk semua negara lainnya. Prakteknya, sekali suatu negara dan patner dagangnya sepakat memotong tarif, biasanya sebagi pertukaran atas pemotongan dalam bidang lainnya, maka pemotongan itu secara otomatis berlaku pula' bagi negara lainnya: Tarif baru ini tidak bisa dinaikkan, kecuali melalui negoisasi dimana seluruh negara juga di beri kompensasi. Bentuk- bentuk proteksi lainnya dilarang.

Dari ketentuan ini maka baik produk dari negara berkembang maupun negara maju terkena tarif bea masuk yang sama. Hal ini tentu saja membuat kelompok negara berkembang sulit mengembangkan industrinya karena tidak bersaing dengan produk-produk dari negara-negara maju dengan teknologi-teknologi canggihnya. Untuk itu kelompok negara berkembang melalui kelompok 77 mengusulkan diberikannya fasilitas GSP sebagai perkecualian dari ketentuan MFN dalam pasal 1 GATT. Fasilitas ini memberikan keleluasaan pada negara-negara maju untuk memberikan pembebasan atau pengurangan tarif bea masuk terhadap produk dari negara berkembang. Negara maju yang telah memberikan GSP tidak perlu memberikan tarif yang sama kepada negara anggota GATT lainnya, sebagaimana yang diisyaratkan oleh pasal 1 GATT. ${ }^{\text {) }}$

Usulan ini kemudian dibicarakan lagi dalam sidang kedua UNCTAD di New Delhi, India, tahun $1968 .{ }^{8)}$ Akhimya pada tanggal 25

5) Republika, 16 Pebruari 1994

Media Informasi Perdagang, Nomor 73/VIII, 1993, Departemen Perdagangan RI.

6) Masalah-masalah Perdagangan, Perjanjian, Hukum Perdata Internasional dan Hak Milik Intelektual, Sudargo Gautama, PT Citra Aditya Bakti, 1992, hal. 7.

7) Segi-segi Hukum Perdata Internasional (GATT dan GSP), PT Citra Aditya Bakti, Bandung, 1994, hal. 107.

8) Republika, 18 Pebruari 1994, Op.Cit. 
Juni 1971, negara-negara maju anggota GATT menyetujui pemberian preferensi atas impor dari negara berkembang, untuk jangka waktu 10 tahun dana dapat diperpanjang lagi untuk jangka waktu berikutnya.

Sampai saat ini, negara yang memberikan sistem preferensi yaitu, Australia, Austria, Kanada, MEE (12 negara), Finlandia, Jepang, Norwegia, Selandia Baru, Swedia, Switzerland, Amerika Serikat, Bulgaria, Cekoslowakia, Polandia, Hongaria dan Rusia. ${ }^{9)}$ Selanjutnya negara pemberi preferensi disebut juga negara donor, sedang negara penerima disebut. benefiaciary country.

Secara umum sistem kerja preferensi ini memiliki 2 sasaran pokok. Yang pertama untuk menjamin agar negara-negara berkembang memperoleh harga lebih baik sekaligus bisa meningkatkan nilai ekspomya. Sedangkan yang ke-2 adalah untuk membantu proses perindustrian atau dengan kata lain untuk membentuk kapasitas industri baru di negara berkembang.

Dalam sistem preferensi ini, terlepas dari siap negara pemberinya, negera donor memang berhak mencabut atau tidak memperpanjang pemberian fasilitas GSP pada waktu tertentu, berdasarkan pertimbangan dan kebijakan negara masing-masing, tergantung pada syarat yang diajukan pada benefiaciary country, saat perjanjian antara mereka satu sama lain dibentuk. Namun secara umum, penghentian ini dilakukan jika negara donor memandang benefiaciary country sudah mampu bersaing di pasaran negara-negara donor. Benefiaciary country yang sudah mencapai tahap ini akan di coret dari daftar penerima atau sering juga dikatakan ia terkena graduation. Contoh kelompok ini adalah negara-negara yang termasuk macan-macan Asia atau NIC (Newly Industrialized Countries) seperti Korea, Taiwan, Hongong, dan Singapura. ${ }^{10)}$

\section{GSP Amerika Serikat}

Semula Amerika tidak bersedia memberikan fasilitas tertentu dan perlakukan khusus berkenaan dengan tarif bea masuk pada negara-negara berkembang, karena khawatir akan merugikan pengusahapengusaha domestiknya. Akan tetapi pada tahun 1967 di Punta del Esta, Uruguay, Presiden Amerika Serikat saat itu, Johnson berubah pikiran. ${ }^{11)}$ Dan akhimya mulai 1 Januari 1976, Amerika Serikat mulai memberi fasilitas GSP-nya pada impor dari negara-negara berkembang. Persyaratanpersyaratan yang diajukan oleh Amerika bagi negara-negara yang ingin mendapatkan fasilitas GSP-nya antara lainberupa kewajiban membuka pasar, mengurangi hambatan- hambatan perdagangan barang, jasa dan investasi, menjamin perlindungan hak-hak milik intelektual, juga melaksanakan perlindungan terhadap hak-hak buruh yang sesuai dengan pengakuan intemasional. Fasilitas bea masuk yang diberikan Amerika, sampai saat ini merupakan yang terbesar dibandingkan yang diberi oleh negara-negara donor lainnya. Indonesia sendiri sebagai salah satu negara berkembang sekaligus benefiaciary country sudah memanfaatkan GSP Amerika sejak tahun 1980 setelah menanda tangani persetujuan tariff bound dengan negara Paman Sam itu, yang tentu saja sudah menyetujui untuk menerima

9) Media Informasi Perdagangan. Op.Cit., hal. 7

10) Segi-segi Hukum Perdata Internasional (GATT dan GSP), Op.Cit., hal. 101.

11) Loc.Cit. 
persyaratan-persyaratan yang ditetapkan oleh pihak Amerika Serikat.

\section{Politik Luar Negeri Indonesia}

Politik Luar Negeri Indonesia yang bebas aktif sejak semula menolak dengan tegas segala macam bentuk atau fasilitas yang diberikan oleh negara lain, yang mengandung penetrasi-penetrasi tertentu di bidang apapun, termasuk mencampuri urusan dalam negeri Indonesia.

Sebagai contoh yang dapat dikemukan disini adalah penolakan Indonesia atas bantuan Belanda yang mengkaitkan pemberian bantuan itu dengan tragedi 12 Nopember 1991 di Timor-Timur. Pihak Indonesia menganggap peristiwa 12 Nopember itu urusan integral Indonesia, dan Belanda telah bertindak terlalu jauh mencampurinya, dengan alasan pelanggaran hak asasi manusia sekalipun. Mata dunia Internasional pun terbuka, bahwa Indonesia tidak bisa di tekan. Ketika Belanda mencoba memperbaharui perjanjian pemberian bantuan ini, Pemerintah Indonesia menolaknya dengan tegas, bahkan sempat memulangkan pekerja Belanda.

Dalam kasus GSP, mirip dengan kasus Belanda di atas, Amerika mencoba melakukan penetrasi-penetrasi terhadap Indonesia dengan iming-iming perpanjangan fasilitas GSP. Kondisi perburuhan termasuk hak asasi manusia, juga beberapa hal lain sebagaimana telah disinggung dalam bagian pendahuluan telah diangkat ke permukaan dan negara-negara berkembang lainnya. Namun bila kita jeli, dibalik tindakan Amerika itu ada maksud-maksud politis tertentu. Memang masalah pemberian GSP ini tidak bisa lepas dari pengaruh politik. Dengan ancaman-ancaman yang telah digunakannya tahun-tahun yang lalu di Amerika sudah berhasil mendobrak pintu masuk bagi film Hollywood ke Jakarta. Amerika juga sudah sukses mendesak Indonesia untuk mengakui intelectual property rights-nya. Tahun ini dengan ancaman yang sama, diduga Amerika ingin meloloskan ekspomya, yaitu ekspor industri jasa. Disamping itu, diduga juga ada kepentingan untuk melicinkan KTT APEC (Asean Pasific Economic Cooperation) yang akan datang.

Melihat ini semua, sebenamya ketakutan yang berlebihan yang sempat melanda berbagai pihak, khususnya pengusaha, tidaklah perlu. Amerika harus berfikir berulang kali sebelum memutuskan untuk menghentikan pemberian fasilitas GSP, karena Amerikapun mempunyai kepentingan, tidak akan begitu saja mereka menghapuskannya. Hal ini juga nampak sebagaimana yang telah dikemukakan oleh Micky kantor dari USTR, 20 Mei 1993 yang lalu, bahwa GSP program masih diperlukan oleh Amerika Serikat berdasarkan alasan pertimbangan-pertimbangan sebagai berikut: $^{12)}$

1.GSP adalah kunci, sebagai alat perdagangan dan bukan sebagai aid (bantuan) bagi perkembangan ekonomi.

2.GSP bisa dipakai sebagai alat politik perdagangan dalam rangka mencapai perubahan-perubahan di negara-negara penerima fasilitas GSP, yaitu di bidang hak milik intelektual dan hak-hak buruh (worker right)

3.GSP dapat membantu perusahaanperusahaan Amerika Serikat agar dapat bersaing terus secara wajar serta dapat menambah lowongan pekerjaan.

4. GSP bisa membantu timbulnya perubahan pasaran dalam ekonomi negara-negara Eropa Timur dan Tengah.

12) Segi-segi HPI, Op.Cit. 
Indonesia memang sudah menyetujui untuk menerima persyaratan- persyaratan yang diajukan Amerika sebagai negara donor dalam persetujuan tariff bound-nya. Namun demikian politik luar negeri kita tidak akan menerima perubahan-perubahan serta perluasan persyaratan yang bermaksud mencampuri urusan domestik Indonesia.

\section{Kondisi Perburuhan di Indonesia}

Patut kita hargai politik Luar Negeri Indonesia yang tidak mau didikte oleh negara lain dalam menentukan policy negara. Prinsip persamaan kedaulatan, dimana tiap anggota $\mathrm{PBB}$ mempunyai persamaan hak untuk menentukan nasib sendiri dipegang teguh oleh Pemerintah Indonesia dalam menentukan arah politik luar negerinya. Demikian juga prinsip non intervensi. Indonesia tidak ingin mencampuri urusan dalam negeri negara lain, sebaliknya Indonesia juga tidak ingin negara lain turut campur dalam masalah dalam negerinya.

Akan tetapi, di balik semua itu Indonesia seharusnya juga perlu instropeksi diri, adakah kaitannya petisi pencabutan GSP yang diajukan oleh dua LSM Amerika Serikat dengan kondisi perburuhan yang ada di Indonesia saat ini, tanpa perlu mengubah haluan politik luar negeri yang diyakini dan dianut dewasa ini.

Kalau mau jujur, sebenarnya Indonesia harus mengakui bahwa kondisi perburuhan yang ada kini, masih sangat memprihatinkan. Masih segar dalam memory kita bagaimana nasib seorang buruh wanita yang gigih memperjuangkan hak-haknya dan teman-teman seprofesinya, harus membayar sangat mahal, mengalami siksaan yang sangat berat sebelum tewas, dan akhimya jenazahnya dionggokan begitu saja di sebuah gubuk terpencil. Sampai saat ini pihak pengadilanpun masih kesulitan untuk menuntaskan kasus ini, sampi- sampai komisi hak asasi manusiapun turun kelapangan untuk mencari fakta-fakta kebenaran materiil kasus yang sempat menggeger intemasional itu. Sampai disini sudah adakah jaminan perlindungan hak-hak seorang buruh di Indonesia?.

Inilah justru yang kemudian menimbulkan celah-celah atau lobang-lobang untuk timbulnya penetrasi dari negara lain. Dapat dikatakan disini bahwa Amerika hendak memancing ikan di air yang keruh, memanfaatkan kekurangan-kekurangan yang ada di Indonesia untuk tujuan-tujuan politisnya.

Sebagaimana telah disinggung dalam bagian pendahuluan, Pemerintah Indonesia dalam hal ini Departemen Tenaga Kerja sudah berupaya untuk memperbaiki kondisi perburuhan di Indonesia. Tidak berlebihan kiranya jika dikatakan bahwa pangkal tolak kondisi perburuhan yang memprihatikan ini adalah masalah upah, karena pemerintah sangat memperhatikan masalah satu ini. Bila kita lihat, hampir semua unjuk rasa yang diikuti dengan pemogokan kaum buruhnya, dilatar belakangi oleh masalah upah. Untuk mengatasi masalah ini pemerintah telah mengeluarkan ketentuan baru tentang kenaikan UMR, bahkan telah memperingatkan perusahaan-perusahaan yang masih membandel dalam masalah UMR ini akan diseret ke pengadilan. Suatu langkah positif yang bagus. Meskipun demikian masih banyak yang harus dipertimbangkan dan diperbaiki oleh pemerintah berkenaan dengan UMR ini.

Selama ini standar yang digunakan dalam menentukan UMR adalah standar kebutuhan fisik minimum (KFM) séorang buruh tanpa mempertimbangkan hal-hal lain yang berkaitan erat dengannya seperti laju inflasi kenaikan barang-barang kebutuhan pokok, dan lain-lain. Dapat dikatakan bahwa 
kenaikan UMR yang ada sekarang baru merupakan kenaikan nominal saja, bukan kenaikan riil.

Munurut Pusat Pengkajian Strategis dan Kijakan (PPSK) Yogyakarta, penetapan UMR yang menggunakan standar KFM suadah kadaluwarsa dan mengandung beberapa kelemahan, antara lain :

1. KFM tidak pernah mengukur dan memperhitungkan kebutuhan non fisik yang berkaitan erat dengan proses pemulihan kemampuan fisik, seperti kebutuhan rekreași. Apalagi termasuk kebutuhan intelektual seperti kebutuhan informasi, pendidikan lanjutan, dan lain sebagainya.

2. KFM membedakan status marital buruh, sehingga sering menjadikannya tidak adil. Seorang buruh pria dibayar berdasarkan satatus maritalnya, sedang seorang buruh wanita dibayar sama dengan buruh pria lajang. Dengan demikian kebutuhan khusus wanita seperti kosmetik, pembalut, yang tidak dibutuhkan oleh kaum pria tidak masuk dalam perhitungan.

Menurut laporan Biro Pusat Statistik (BPS) tahun 1992, rata-rata besamya UMR buruh di Indonesia sekitar $63 \%$ dibawah kebutuhan fisik minimum. Yang agak lumayan di Sumatera Utara dan Jambi, $92 \%$ di bawah KFM. Sedangkan yang paling memprihatinkan terjadi di Sulawesi Tengah, Sulawesi Selatan, dan Bengkulu, hanya sekita 42- $48 \%$ di bawah KFM. Dari sini dapat dibayangkan kalau KFM saja belum terpenuhi, masih ada yang $42 \%$ dibawahnya, yang berarti buruh-buruh di Indonesia belum dapat mencukupi kebutuhan pokok hidupnya, bagaimana dengan pemenuhan kebutuhan non fisik yang penting untuk pemulihan kemampuan fisik seperti yang dikemukakan oleh PPSK Yogyakarta?
Tingkat buruh di Indonesia relatif lebih rendah di banding negara-negara lain, di kawasan ASEAN sekalipun. Upaya peningkatan upah untuk kesejahteraan buruh ini memang tidak bisa hanya berasal dari satu pihak saja, dalam hal ini pemerintah cq Departemen Tenaga Kerja, tapi harus ada peran serta aktif dari pihak pengusaha. Sampai saat ini sebagian besar pengusaha masih hanya memikirkan keuntungan pribadinya semata, mengeruk keuntungan sebanyak mungkin tanpa memperdulikan nasib apalagi kesejahteraan buruh-buruhnya. Buruh memang berada pada posisi yang lemah. Ia butuh pekerjaan untuk hidup diri dan keluarganya. Sedang untuk mendapatkan pekerjaan tanpa keahlian apapun selain tenaga bukanlah hal yang mudah diabad komputer ini. Kalaupun akhir-akhir ini banyak unjuk rasa diikuti pemogokan, dan tak jarang pula disertai kekerasan dan pengrusakan menuntut kenaikan upah, bukanlah suatu penyelesaian yang baik. Tak Jarang buruh- buruh ini dikendalikan oleh pihak ketiga yang ingin memanfaatkan situasi untuk keuntungannya. Akhirnya stabilitas keamanan terganggu, dan semua pihak baik buruh, pengusaha maupun pemerintah rugi. Disinilah pentingnya pengaturan yang lebih baik dan tegas dari pemerintah untuk mencapai cita-cita pengentasan kemiskinan, mempersempit jurang pemisah antara si kaya dan si miskin sebagaimana yang di canangkan dalam PJPT II.

Masih berkaitan dengan kondisi perburuhan di Indonesia, yang juga diajukan dalam petisi pencabutan fasilitas GSP adalah masalah serikat buruh. Kebijakan yang ada sekarang masih sangat memprihatinkan. Pengusaha berhak menentukan kriteria siapa yang berkondite baik dan dapat duduk di 
kepengurusan SPSI. Akibatnya seperti yang kita lihat SPSI ini muncul, tidak aspiratif dan tidak akomodatif menyuarakan kepentingankepentingan buruh yang seharusnya menjadi tugasnya, malahan justru lebih memihak pada pengusaha dan pemerintah. Lembaga ini justru asing bagi para buruh, sehingga bila terjadi perselisihan dengan pengusaha mereka tidak lari ke SPSI tapi ke DPR atau lembaga-lembaga lainnya. Untuk itu sangat penting kiranya bagi pemerintah untuk meninjau mekanisme yang sudah ada untuk Iebih memfungsikan SPSI

Disamping masalah upah dan SPSI, masih ada satu masalah lagi yang penting dibicarakan berkaitan dengan kondisi perburuhan Indonesia, yaitu masalah keterlibatan militer dalam sengketa- sengketa perburuhan. Meskipun sebagaimana telah dikemukan pemerintah telah mencabut salah satu SK nya yang melegitimasi intervensi militer, dan menggantikannya dengan ketentuan yang baru, namun sebenamya ini tidak berarti banyak. Keputusan Nomor 15 A tahun 1994 ternyata masih diperkenankan intervensi militer, meskipun dengan syarat harus melalui instansi terkait yang dicantumkan sebagai pihak-pihak yang dapat dimintakan untuk ikut menyelesaikan perselisihan - perburuhan. Disamping itu keputusan Bakorstanas Nomor 02 tahun 1990 tentang pedoman penanggulangan kasus hubungan industrial, memberi perhatian yang cukup besar pada masalah sengketa industrial, dalam upayanya menegakan stabilitas keamanan. Memang masalah stabilitas keamanan adałah masalah yang rawan, namun seyogyanya sedapat mungkin militer tidak dilibatkan dalam kasus indistrial ini. Untuk itu suatu peraturan yang tegas tentang - batas-batas kewenangan militer dalam kasus indistrial sangatlah diperluḳan.

\section{Kesimpulan}

Dari apa yang sudah diuraikan diatas, dapat kita lihat adanya kaitan yang sangat erat antara masalah GSP, kondisi perburuhan di Indonesia, dan politik Luar Negeri Indonesia. Kondisi Perburuhan Indonesia yang masih sangat memprihatinkan dimanfaakkan. oleh Amerika Serikat untuk kepentingankepentingan politisnya, yaitu dengan mengkaitkan pemberian fasilitas GSP terhadap produk ekspor Indonesia ke negeri itu dengan kondisi perburuhan di Indonesia. Meskipun demikian, masalah ini tidaklah perlu sampai merubah haluan politik Luar Negeri Indonesia. Kasus penolakan bantuan dari Belanda beberapa waktu yang lalu, juga kasus ketegangan Amerika 'Serikat dengan Cina, dalam masalah MFN-nya, dapat dijadikan pegangan, bahwa Indonesia hanya akan menerima bantuan dari Luar Negeri sepanjang tidak mengkaitkannya dengan masalah dalam negeri Indonesia, juga tidak disertai dengan tekanan-tekanan macam apapun. Melalui politik luar negerinya, Indonesia harus menunjukan sifat mandari.

Hikmah yang dapat dipetik dari kasus GSP ini adalah bahwa Pemerintah Indonesia memang harus memperbaiki kondisi perburuhan yang ada saat ini, terlepas dari adanya ancaman pencabutan fasilitas GSP atau tidak. Meningkatkan kesejahteraan bangsa pada umumnya, kaum buruh khusunya, agar tidak dimanfaatkan oleh negara lain untuk kepentingan-kepentingan politisnya.

\section{Biodata}

* Sefriani, SH., adalah staf pengajar FH-UII. Alumnus Fakultas Hukum Universitas Gadjah Mada Yogyakarta. 